\title{
Histopathological study of Non-neoplastic \& Neoplastic ovarian lesions in a tertiary care hospital in Gujarat, India
}

\author{
Maru A.M', Menapara C.B. ${ }^{2}$ \\ ${ }^{1}$ Dr. Alpesh M Maru, Assistant Professors, ${ }^{2}$ Dr. Chiragkumar B. Menapara, Assistant Professors, both authors are \\ affiliated with Department of Pathology, GMERS Medical College\& Hospital, Junagadh, Gujarat, India.
}

Corresponding Author: Dr. Chiragkumar B. Menapara, Assistant Professors; Department of Pathology, GMERS Medical College \& Hospital, Junagadh, Gujarat, India. E-mail: drmaru28@gmail.com

\begin{abstract}
Aims \& Objectives: (1) To know about various histopathological types of ovarian lesions presented and diagnosed at our institute. (2) To study the incidence of ovarian lesions with respect to patient's age. (3) To study the frequency of ovarian lesions in terms of non-neoplastic or neoplastic, benign or malignant, unilateral or bilateral, etc. Materials \& Methods: The present study was performed at the Department of Pathology, GMERS Medical College \& HospitalJunagadh (Gujarat, India) from January 2015 to December 2018 and includes 100 cases of ovarian lesions diagnosed on both clinical \& histopathological basis. We have received ovarian specimens and performed routine grossing and H\& $\mathrm{E}$ staining procedure. We have included parameters like Age wise incidence, Nature of Lesion, Frequency \& Laterality in this present study. Results: Out of 100 cases, $89 \%$ are unilateral and 11\% are bilateral. 52\% lesions are Benign Neoplasms, 44\% lesions are Non-neoplastic Cysts and 4\% lesions are Borderline \& Malignant Neoplasms. Majority of cases (58\%) belong to age group of 20-39 years. Among Non-neoplastic Lesions, Follicular Cyst is common \& frequently bilateral while among Benign Neoplasms, Serous Cystadenoma is common \& frequently bilateral. Conclusion: Ovarian Lesions both non-neoplastic and neoplastic include a variety of morphological features and show a particular age wise incidence. Role of histopathological evaluation remains always important in both diagnosis \& management of such cases, particularly in cases of Malignant Lesions in order to save the patient's life.
\end{abstract}

Key words: Non-neoplastic, Benign, Borderline, Malignant, Follicular Cyst, Serous Cystadenoma

\section{Introduction}

Ovarian enlargements (lesions), cystic or solid, may occur at any age [1]. These enlargements may be Nonneoplastic or Neoplastic in nature. Non-Neoplastic Enlargements include Simple Follicular Cysts, Corpus Leuteal Cysts, Chocolate Cysts due to Endometriosis, Twisted Hemorrhagic Cysts, Polycystic Ovarian Disease (PCOD), Various Inflammatory Lesions, etc. To define a functional non-neoplastic cyst, its size or diameter must be at least $3 \mathrm{~cm}$, but not more than $7 \mathrm{~cm}$ [1]. Non-Neoplastic Enlargements develop almost exclusively during the childbearing years.

They may be asymptomatic or produce local discomfort, menstrual disturbances, infertility, or in rare cases cause acute symptoms due to complications like haemorrhage, rupture or torsion [1]. Neoplastic disorders or lesionsof Ovary can arise from (1) Mullerian epithelium, (2) Germ cells or (3) Sex cord

Manuscript received: $20^{\text {th }}$ January 2019

Reviewed: $30^{\text {th }}$ January 2019

Author Corrected: $7^{\text {th }}$ February 2019

Accepted for Publication: $11^{\text {th }}$ February 2019
Stromal cells [2]. Classification of Ovarian Neoplasms given by WHO is completely based upon the tissue of origin. It includes a variety of entities like Surface Epithelial Tumors, Sex cord Stromal Tumors, Pure or Mixed Germ Cell Tumors, Gonadoblastoma, Soft Tissue Tumors, Metastatic Tumors, Unclassified Tumors, etc. Surface Epithelial Tumors are further categorized into benign, borderline and malignant $[1,3]$. Ovarian neoplasms behave in diverse way and generally escape the detection until they attain a larger size. This is primarily due to the reason that either the symptoms are vague or most of these are asymptomatic therefore they manifest over a time period due to no definite screening program. Therefore, diagnosis of various histological patterns of ovarian tumors is very important in the treatment and prognosis. [2]

\section{Aims \& Objectives}

- To know about various histopathological types of ovarian lesions presented and diagnosed at our institute. 


\section{Original Research Article}

- To study the incidence ofovarian lesions with respect to patient's age

- To study the frequency of ovarian lesions in terms of non-neoplastic or neoplastic, benign or malignant, unilateral or bilateral, etc.

\section{Material \& Method}

The present retrospective studywas performed at the Department of Pathology, GMERS Medical College\& Hospital-Junagadh (Gujarat, India) from January 2015 to December 2018 for a period of 4 years. It includes a total number of 100 random cases of ovarian lesions diagnosed initially on the basis of clinical findings and finally on the basis of histopathological examination.

\section{Nature of Specimens}

- Solitary Salpingooophorectomy specimens, Unilateral or Bilateral

- Hysterectomy with Unilateral Salpingooophorectomy specimens

- Hysterectomy with Bilateral Salpingooophorectomy specimens
Inclusion Criteria: All ovarian biopsy with abnormal findings on sonography.

\section{Exclusion Criteria:}

1. History of previous chemotherapy or radiotherapy

2. Age below 20 years.

These specimens have been received from Gynecology Department with sufficient \& relevant clinical and radiological findings in a specific Performa for further Histopathological Evaluation at our Department. After a number of necessary technical steps like Fixation in 10\% Formalin, Gross Examination, Surgical Dissection, Tissue Processing, Paraffin Embedding, Microtomy, staining with routine $\mathrm{H}-\mathrm{E}$ method \& Mounting of Slides using DPX, Microscopic Slides have been made available for further evaluation \& final diagnosis.All slides have been viewed by at least two Pathologists before final reporting and all lesions have beenclassified using WHO guidelines. Data are plotted and statistical analysis was carried out with the help of SPSS (Statistical packages for social science) and by using $\mathrm{X}^{2}$ - chi square test. $\mathrm{P}$ value less than 0.001 is significant.

\section{Results}

A total of 100 specimens of ovarian lesions have been received for histopathological evaluation at our department \& out of them, 89 lesions are unilateral and 11 lesions are bilateral. 52\% lesions are Benign Neoplasms, 44\% lesions are Nonneoplastic Cysts and 4\% lesions are Borderline \& Malignant Neoplasms. Histopathological Categorization of Various Ovarian Lesions is given below in Table no.1 and their Age-wise incidence is given below in Table no.2.

Table No-1: Histopathological Categorization of various Ovarian Lesions

\begin{tabular}{|c|c|c|c|c|}
\hline Sr.No. & HistopathologicalDiagnosis or Category & $\begin{array}{c}\text { Number of } \\
\text { Cases and \% }\end{array}$ & $\begin{array}{c}\text { Unilateral } \\
\text { Cases }\end{array}$ & $\begin{array}{c}\text { Bilateral } \\
\text { Cases }\end{array}$ \\
\hline \multicolumn{5}{|c|}{ Non-neoplastic lesions } \\
\hline 1 & Follicular Cysts & 20 & 17 & 03 \\
\hline 2 & Corpus Leuteal Cysts & 14 & 11 & 03 \\
\hline 3 & Hemorrhagic Twisted Ovarian Cysts & 06 & 06 & -- \\
\hline 4 & Endometriosis \& Chocolate Cysts & 04 & 04 & -- \\
\hline \multicolumn{5}{|c|}{ Benign neoplasms } \\
\hline 5 & Serous Cystadenoma & 28 & 24 & 04 \\
\hline 6 & Mature Cystic Teratoma & 13 & 13 & -- \\
\hline 7 & Mucinous Cystadenoma & 06 & 05 & 01 \\
\hline 8 & Serous Cystadenofibroma & 03 & 03 & -- \\
\hline 9 & Mature Teratoma with Struma Ovarii & 01 & 01 & -- \\
\hline 10 & Brenner's Tumor (Benign) & 01 & 01 & -- \\
\hline \multicolumn{5}{|c|}{ Borderline \& malignant neoplasms } \\
\hline 11 & Borderline Mucinous Tumor & 01 & 01 & -- \\
\hline 12 & Papillary Serous Cystadenocarcinoma & 01 & 01 & -- \\
\hline 13 & Granulosa Cell Tumor of Adult Type & 01 & 01 & -- \\
\hline \multirow[t]{2}{*}{14} & Dysgerminoma & 01 & 01 & -- \\
\hline & Total & 100 & 89 & 11 \\
\hline
\end{tabular}


TableNo.-2: Age-wise Incidence of various Ovarian Lesions.

Original Research Article

\begin{tabular}{|c|c|c|c|c|c|}
\hline $\begin{array}{l}\text { Sr. } \\
\text { No. }\end{array}$ & $\begin{array}{l}\text { Histopathological } \\
\text { Diagnosis or Category }\end{array}$ & $\begin{array}{l}20-39 \\
\text { years }\end{array}$ & $\begin{array}{l}40-59 \\
\text { years }\end{array}$ & $\begin{array}{l}60 \text { years } \& \\
\text { above }\end{array}$ & Tota \\
\hline 1 & Follicular Cysts & 14 & 06 & -- & 20 \\
\hline 2 & Corpus Leuteal Cysts & 08 & 06 & -- & 14 \\
\hline 3 & Hemorrhagic Twisted Ovarian Cysts & 06 & -- & -- & 06 \\
\hline 4 & Endometriosis \& Chocolate Cysts & -- & 03 & 01 & 04 \\
\hline 5 & Serous Cystadenoma & 15 & 08 & 05 & 28 \\
\hline 6 & Mature Cystic Teratoma & 07 & 05 & 01 & 13 \\
\hline 7 & Mucinous Cystadenoma & 04 & 01 & 01 & 06 \\
\hline 8 & Serous Cystadenofibroma & 03 & -- & -- & $\mathbf{0 3}$ \\
\hline 9 & Mature Teratoma with Struma Ovarii & -- & 01 & -- & 01 \\
\hline 10 & Brenner's Tumor (Benign) & -- & 01 & -- & 01 \\
\hline 11 & Borderline Mucinous Tumor & -- & 01 & -- & 01 \\
\hline 12 & Papillary Serous Cystadenocarcinoma & -- & -- & 01 & 01 \\
\hline 13 & Granulosa Cell Tumor of Adult Type & -- & 01 & -- & 01 \\
\hline 14 & Dysgerminoma & 01 & -- & -- & 01 \\
\hline & Total & 58 & 32 & 10 & 100 \\
\hline
\end{tabular}

As mentioned above in both tables, Simple Follicular Cysts are the commonest among all Non-neoplastic Cystic Lesions and often bilateral. Non-neoplastic Cysts are seen in comparatively younger females belonging to age group of 20-39 years and quite rare after menopause because of complete cessation of normal \& regular menstrual cycles.

Among various benign neoplasms, Serous Cystadenoma is the commonest \& often bilateral. Next common benign neoplasm is Mature Cystic Teratoma or Dermoid Cyst of Ovary that is often unilateral. Both of these benign tumors can occur at any age but commonly seen before 40 years of age during reproductive period of life.

Other benign neoplasms like Mucinous Cystadenoma and Serous Cystadenofibroma are also seen in younger females. Brenner's Tumor is an uncommon subtype of the surface epithelial tumors of ovary and Majority of the cases are benign in nature.

This tumor is particularly seen between $40-60$ years of age. Our present study includes total 4 cases of Borderline \& Malignant Neoplasms namely Serous Cystadenocarcinoma (65 years old), Granulosa Cell Tumor of Adult Type (45 years old), Dysgerminoma (32 years old) and Borderline Mucinous Tumor (48 years old).

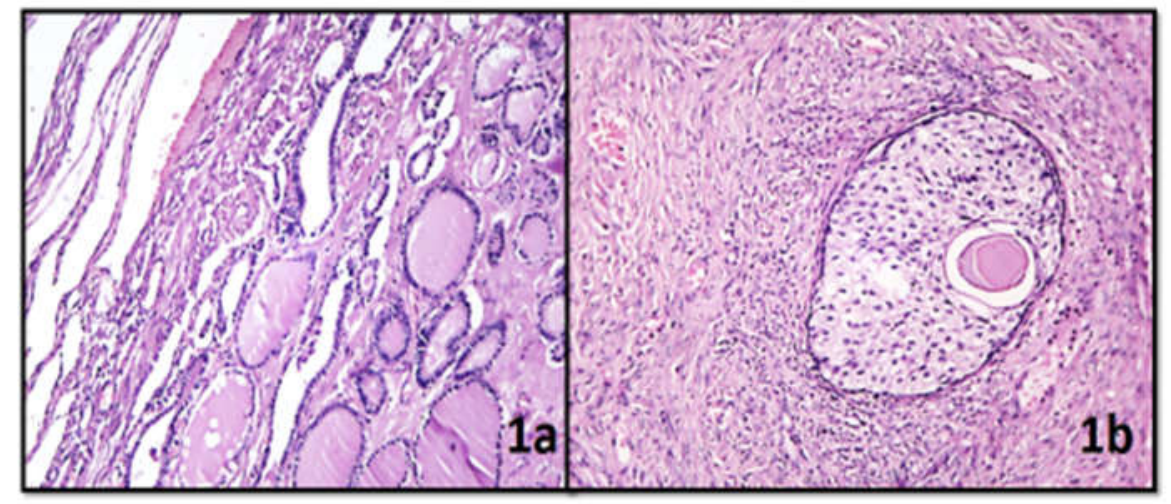

Fig 1a shows Struma Ovarii with extensive normal looking thyroid tissue. 1b shows Benign Brenner's Tumor with characteristic transitional or urothelial component giving a biphasic appearance. 
Original Research Article

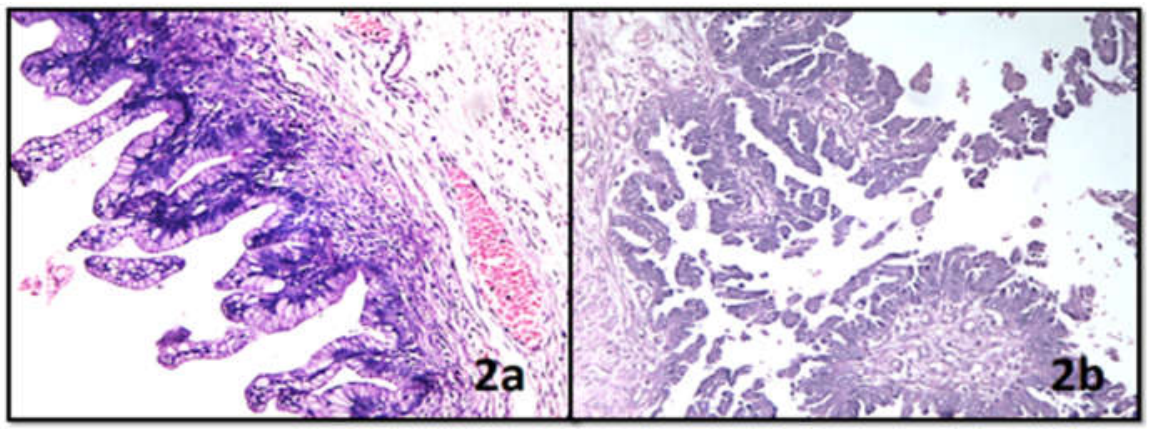

Fig 2a shows Borderline Mucinous Tumor of ovary, a tumor with nuclear atypia and having low malignant potential (in-between benign \& malignant). 2b shows Papillary Serous Cystadenocarcinoma of ovary with features of anaplasia and aggressiveness.

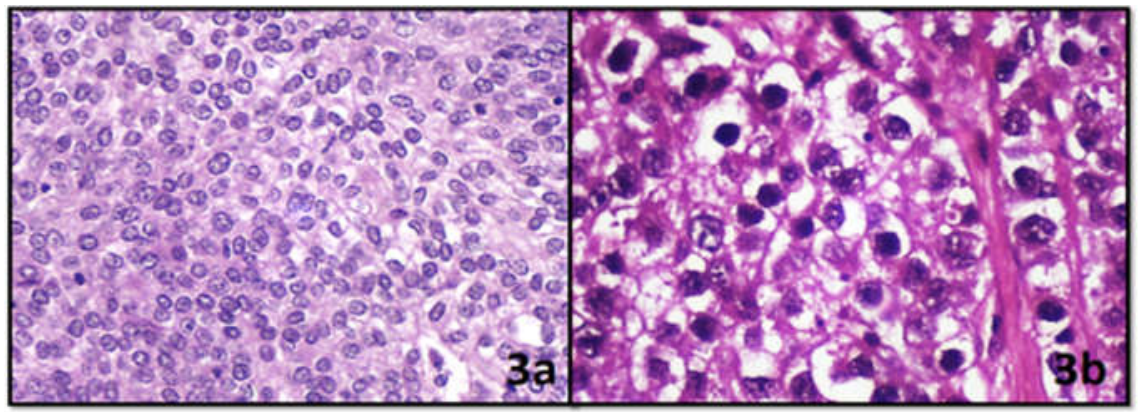

Fig no. 3a shows Granulosa Cell Tumor of Adult Type with characteristic Coffee-bean Nuclei. $3 \mathrm{~b}$ shows Dysgerminoma of Ovary looking more or less similar to the classical seminoma of the testis having clear looking cells.

Figure no. 1a, 1b, 2a \& $2 \mathrm{~b}$ shows microscopic photographic images of various lesions under low power magnification (H \& E stain, 100x) while figure no. 3a \& 3b shows images under high power magnification (H \& E stain, 400x).

\section{Discussion}

Our present study includes total 100 cases of Ovarian Lesions diagnosed finally on histopathological basis. Out of them, $89 \%$ cases show unilateral lesion and $11 \%$ cases show bilateral lesions. Prakash et al found similar observation in his study with $90.9 \%$ unilateral \& 9.2\% bilateral lesions [4], Gurung P et al [5] with $88.15 \%$ unilateral \& $11.85 \%$ bilateral lesions, Prabhakar BR\& Kalyani M [6]with 90.9\% unilateral \& 9.1\% bilateral lesionsand by Couto F et al[7]having $91.2 \%$ unilateral ovarian lesions \& $8.7 \%$ bilateral lesions. So we can say that unilateral lesions are more frequent than bilateral ones and all the studies show comparable outcomes [4,5,6,7]. Broad categorization of these lesions includes Non-neoplastic cysts, Benign Neoplasms and Borderline-Malignant Neoplasms. Our present study shows $44 \%$ cases of Non-neoplastic Cysts. Similar studies like those done by Prakash A et al [4] and by Gurung P et al [5] shows 44.10\% cases and $43.70 \%$ cases of Non-neoplastic Cysts respectively. In the study done by Zaman et al[8], $68.87 \%$ of the lesions are non- neoplastic in nature that is somewhat higher than other studies. Among all non-neoplastic cystic enlargements, Simple Follicular Cyst, unilateral or bilateral is the commonest one followed by Corpus Leuteal Cyst.

Both of them are frequently seen among women of reproductive age and perimenopausal age. Our present study shows $20 \%$ of Follicular Cysts \& 14\% of Corpus Leuteal Cysts respectively. Study done by Prakash A et al [4] shows 20.1\% of Follicular Cysts \& 10.9\% of Corpus Leuteal Cysts respectively. Gurung P et al [5]reported 17.0\% of Endometriotic or Chocolate cyst, $10.4 \%$ of Simple Follicular Cyst and 9.6\% of Corpus Leuteal Cyst and this result or outcome is not comparable with that of our present study. Our present study shows $52 \%$ cases of benign neoplasms as well as $4 \%$ cases of borderline \& malignant neoplasms. Study done by Prakash A et al [4] shows $54.14 \%$ cases of benign neoplasms as well as $1.74 \%$ cases of borderline \& malignant neoplasms. Among benign neoplasms, Serous Cystadenoma is the commonest one followed by Mature Cystic Teratoma (Dermoid Cyst) or Mucinous Cystadenoma. Our present study shows 28\% cases of Serous Cystadenoma, 13\% cases of Mature Cystic Teratoma and 6\% cases of Mucinous Cystadenoma respectively. Yogambal M et al[9] has reported 21.4\% cases of Serous Cystadenoma and 19.9\% cases of Mature Cystic Teratoma. 
Original Research Article

Pudasaini S et al[10] has reported $40.2 \%$ cases of Serous Cystadenoma, $15.7 \%$ cases of Mature Cystic Teratoma and 9.8\% cases of Mucinous Cystadenoma. Maliheh et al[11] has reported 38\% cases of Serous Cystadenoma, $30 \%$ cases of Mature Cystic Teratoma and 22\% cases of Mucinous Cystadenoma. Mondal et al [12] has reported 29.9\% cases of Serous Cystadenoma, $15.9 \%$ cases of Mature Cystic Teratoma and $11.1 \%$ cases of mucinous cystadenoma. Iqbal et al [13] has reported 38.5\% cases of Serous Cystadenoma followed by 30.8\% cases of Mature Cystic Teratoma. Yasmin et al [14] has reported 24\% cases of Serous Cystadenoma followed by $18 \%$ cases of Mature Cystic Teratoma. Sowe can say that outcome of all these similar studies are comparable with that of our present study.

In our study, majority of the patients (58\%) belong to age group of 20-39 years followed by age group of 40-59 years $(32 \%)$ and 60 years or more (10\%). In our study we have not included patients who are below 20 years of age. Comparison of this age distribution with that of other similar studies is mentioned below in table no. 3 .

Table No.-3: Comparison of Age Distribution of patients with ovarian lesions.

\begin{tabular}{|l|c|c|c|c|}
\hline \multirow{2}{*}{ Name of the Study } & \multicolumn{4}{|c|}{ Age Groups in Years } \\
\cline { 2 - 5 } & $\mathbf{0 - 1 9}$ & $\mathbf{2 0 - 3 9}$ & $\mathbf{4 0 - 5 9}$ & $\mathbf{6 0}$ \& above \\
\hline Ramachandran et al $[15]$ & $7.9 \%$ & $53 \%$ & $30 \%$ & $9.1 \%$ \\
\hline Pilli et al [16] & $7 \%$ & $58 \%$ & $30 \%$ & $5 \%$ \\
\hline Kar et al [17] & $7.4 \%$ & $41.7 \%$ & $46.2 \%$ & $4.4 \%$ \\
\hline Prakash A et al [4] & $5.7 \%$ & $53.4 \%$ & $36.6 \%$ & $4.3 \%$ \\
\hline Present Study & ---- & $58 \%$ & $32 \%$ & $10 \%$ \\
\hline
\end{tabular}

So we can say that results of our present study are in concordance with that of other similar studies. Ovarian lesions particularly non-neoplastic cysts \& benign neoplasms are commonly seen in age group of 20-39 years of age.

Our present study includes four cases of borderline and malignant lesions. All of them are Unilateral and show different age wise incidences. Borderline Mucinous Tumor is seen at the age of 48 years. Prakash A et al [4] has also reported one case of Borderline Mucinous Tumor with age of 35 years. We have reported one case of Papillary Serous Cystadenocarcinoma in 65 years old female patient. Prakash A et al [4] has also reported one similar case with age of 56 years. Gurung P et al [5] has reported five such cases with age range of 38 to 66 years. Our present study includes one case of Dysgerminoma of Ovary with age of 32 years. Modi D et al [2] has reported one case of Dysgerminoma with age less than 20 years. Our present study also includes one case of Adult type Granulosa Cell Tumor who is 45 years old. Modi D et al [2] has reported three such cases out of which, two belongs to age group of 31-40 years and one belongs to age group of 41-50 years. Hatwal D et al [18] has reported one case of Granulosa Cell Tumor of Adult type who is 45 years old. So we can say that age wise incidence of Borderline \& Malignant Neoplasms of our present study also correlate with that of other similar studies. Dysgerminoma is a malignant neoplasm of younger females while Borderline tumors and Granulosa cell tumor of Adult type are commonly seen during middle age or perimenopausal age. Serous Cystadenocarcinoma occurs at comparatively older age, usually beyond 60 years.

\section{Conclusion}

Ovarian Lesions or Enlargements, both non-neoplastic and neoplastic include a variety of morphological features and show a particular age wise incidence. Among non-neoplastic lesions, simple follicular cyst is common while among benign tumors, serous cystadenoma is common. Both are frequently bilateral. Malignant Neoplasms of Ovary are rare as compared to Benign Neoplasms and Non-neoplastic Lesions, but require a specific attention during diagnosis on both clinical and pathological basis in order to save the patient's life.

Role of histopathological evaluation remains always important in diagnosis and management of such cases along with clinical and radiological evaluations. Histopathological study is useful to predict nature and course of ovarian lesions so that future worse outcome can be prevented with early intervention and marker study.

\section{Contribution from authors}

- Dr. Alpesh Maru: Data collection, analysis and preparation of manuscript.

- Dr. Chirag Menpara: Analysis and preparation of manuscript \& critical revision.

Findings: Nil; Conflict of Interest: None initiated Permission from IRB: Yes 
Original Research Article

\section{References}

1. Padubidri VG, Daftary SN. Howkins \& Bourne. Pattern of ovarian lesions, Shaw's Textbook of Gynecology, $16^{\text {th }}$ edition. Elsevier; 2014:429-36.

2. Modi D, Rathod GB, Delwadia KN, Goswami HM. Histopathological pattern of neoplastic ovarian lesions. IAIM. 2016; 3(1):51-7.

3. Vinay Kumar, Abul K. Abbas, Jon C. Aster pathology of female genital tract, Robbins and Cotran Pathological Basis of Disease, $9^{\text {th }}$ edition (II). Elsevier; 2015 (22):1023.

4. Prakash A, Chinthakindi S, Duraiswami R, Indira V. Histopathological study of ovarian lesions in a tertiary care center in Hyderabad, India: a retrospective fiveyear study Int J Adv Med. 2017; 4(3):745-49.

5. Gurung P, Hirachand S, Pradhanang S. Histopathological study of ovarian cystic lesions in Tertiary Care Hospital of Kathmandu, Nepal. Journal of Institute of Medicine 2013, 35(3):44-47.

6. Prabhakar BR, Maingi K. Ovarian tumoursprevalence in Punjab. Indian J Pathol Microbiol. 1989 Oct; 32 (4):276-81.

7. Couto F, Nadkarni NS, Rebello MJ. Ovarian tumors in Goa. A Clinicopathological study. J Obstet Gynecol of India. 1993; 43(3):408-12.

8. Zaman S, Majid S, Hussain M, et al. A retrospective study of ovarian tumours and tumour-like lesions. J Ayub Med Coll Abbottabad. 2010Jan-Mar;22(1):104-8.

9. Yogambal M, Arunalatha P, Chandramouleeswari K, Palaniappan V. Ovarian tumors-Incidence and distribution in a tertiary referral center in South India. IOSR J Dent Med Sci. 2014; 13(2):1400-3.
10. Pudasaini S, Lakhey M, Hirachand S, et al. A study of ovarian cyst in a tertiary hospital of Kathmandu valley. Nepal Med Coll J. 2011 Mar;13(1):39-41.

11. Maliheh A, et al. Surgical Histopathology of Benign Ovarian Cysts: A Multicenter Study. Iranian Journal of Pathology 2010; 5(3): 132-6.

12. Mondal SK, Et al. Histologic pattern, bilaterality and clinical evaluation of 957 ovarian neoplasms: a 10 years study in a tertiary hospital of Eastern India. J Can Res Ther2011;7:433-7.

13. Iqbal J et al. Pattern of Ovarian Pathologies. Journal of RawalpindiMedicalCollege(JRMC)2013;17(1):113-5

14. Yasmin S, Yasmin A, Asif M. Clinicohistological pattern of ovarian tumours in Peshawar region. J Ayub Med Coll Abbottabad. 2008 Oct-Dec;20(4):11-3.

15. Ramachandran G, Harilal KR, Chinnamma K, Thangavelu H. Ovarian neoplasms- A study of 903 cases. J Obstet Gynecol India 1972; 22:309 -15.

16. Pilli GS, Suneeta KP, Dhaded AV, et al. Ovarian tumours: a study of 282 cases. J Indian Med Assoc. 2002 Jul;100(7):420, 423-4, 447.

17. Kar T, Kar A, Mohapatra PC. Intra-operative cytology of ovarian tumors. J Obstet Gynecol India. $2005 ; 55(4): 345-9$.

18. Hatwal D, Choudhari S, Batra N, Bhatt P, Bhatt S. Clinico-histopathological analysis of neoplastic and non-neoplastic lesion of ovary in Garhwal region of Uttarakhand: A 4 year study at tertiary level hospital. Indian Journal of Pathology and Oncology, April-June 2016; 3(2):133-140.

\section{How to cite this article?}

Maru A.M, Menapara C.B. Histopathological study of Non-neoplastic \& Neoplastic ovarian lesions in a tertiary care hospital in Gujarat, India. Trop J Path Micro 2019;5(2):63-68.doi:10.17511/jopm.2019.i02.03. 